\title{
Digital Comic Platform Mapping In Improving The Creative Industry Potential
}

\author{
Sayid Mataram \\ Universitas Sebelas Maret \\ sayidmataram@staff.uns.ac.id
}

\author{
Deny Tri Ardianto \\ Universitas Sebelas Maret \\ denytri@staff.uns.ac.id
}

\begin{abstract}
Digital platforms in the field of illustrations such as comics have been growing nowadays. This is inseparable from the development of new media technologies that have transformed many analog and manual mediums into digital and automatic ones. Changes in the medium lead to many variations in the presentations. In comics, there are three digital platforms known today, namely: mobile applications, networking sites, and electronic galleries. However, not all platforms are actively responded by users of the digital technology media. This research applied descriptive qualitative research methods, with interview techniques and polling on students of Visual Communication Design study program in Indonesia. This research seeks to map which digital comic platform is the most widely used or accessible that affects the development of creative industries in Indonesia. The results of the popularity analysis on the digital comic platform will provide an overview on which existing factors in a digital platform that could be a reference platform in developing digital technology based on comics.
\end{abstract}

Keywords: Comic, digital platform, new media

\section{INTRODUCTION}

The current technological developments have changed many aspects in life, both in terms of process and working media from analog to digital. One form of the changes is digital platform that has been used in various fields including in the field of fine arts. The digital platforms in the field of art include multimedia, animation, film, painting and drawing, including comics. Similar with art galleries, digital platform will showcase works, curatorial, and forums, both of which are merely discussions and buying and selling. With many potentials of art works that can be seen and displayed through the digital platform, it will provide opportunities for the creative industries.

The development of the comic world that previously only used print media (newspapers, magazines, books) has now being adapted with digital technology-based media.

Indonesia is currently promoting the spirit of welcoming the 4.0 industrial revolution which is identical with the use of digital-based technology. The movement of the creative economy is of course needed by the potential human resources. Digital platform technology certainly facilitates the actors engaged in the creative industry to recruit workers and make reference works. One form of creative industry in Indonesia is the comic industry.

The comic industry always requires new creative personnels to stay in business. The digital platform will provide a large selection of potential personnels in this industry. The digital platform is available in software application form, social media form, digital art gallery site form, and comic-specific network site form. Account owners on digital platforms can then put their work as a portfolio to be shown to the public. The account owners consist of professionals and amateurs in the comic and illustration fields.

The purpose of this research is to examine the effectiveness of digital platforms for comics in the comic industry and creative industries in Indonesia by mapping of the use of digital platforms, so that the potential that has an important role in the existence and sustainability of the comic industry in particular and for the progress of the country's creative industry in general.

\section{LITERATURE REVIEW}

Researches on comics, especially those that discuss the structure and constituent elements, have been widely carried out. One of them was about the comic visual language carried out by Sayid Mataram (2015) entitled "The Visual Language of Wayang Comics by R.A. Kosasih". Novi Kurnia in her article entitled "The Development of Communication and New Media Technology: Implications for Communication Theory" (2005), discusses the influences and effects of new media presence in providing real change in society as a form of technological progress. The research conducted by Irawati Tirtaatmaja, Nina Nurviana, and Alvanov Spalanzani, entitled "Mapping of Indonesian Comics in the period 1995-2008" (2012), has presented the mapping of comic elements from the period determination (the spirit of competition, the closeness of the storyline to everyday life, and the appearance of comic-themed activities, extrinsic aspects (publisher, author, year of publication, printed techniques and formats), and intrinsic aspects(character and characterization, story and visual narrative, place and time setting). The research was very helpful in describing a new period of comics that came after the 1990s period in Indonesia, which was known as the era of the entry of foreign comics in translation format, in the form of accepting a change and addressing the changing era. The study also discusses the comic format that follows the trend of Japanese comics (manga). However, the research is only limited to the print comic platform and has not touched the digital comic platform. This was explained in a discussion about the extracurricular element of mentioning the publisher and the print format and format. All of the above researches only focuses on the printed form of 
comic and have not discussed comic in the digital platforms. Therefore this research will discuss comic media in addition to print, namely in the form of digital platforms.

Jatnika and Hermawan in his article, "Being a True Man: Masculinity in Indonesian online Webtoon Comics" (2018), discuss about the context of masculinity in the No Homo comic as one of the webtoon products. The digital comic discusses the relationship between people's perceptions as the watching party of gossip in the community regarding gender relations. The issue that develops in the community becomes an interesting idea that was packaged in the webtoon media. In addition there was also a research in the form of webtoon product planning that took the comic idea from the health theme, namely the relationship between diet and blood type. The research was conducted by Amanda, N., Dwi W., H., Zacky, A., entitled "The Design of Digital Comics Using the LINE Webtoon Application About Diet in Accordance with Blood Type for Teens" (2016). This research was actually a design for the final project which will later be published through the Line Webtoon application. This research was similar with the object of Jatnika and Hermawan's research that raised the issue or case in the community into digital comic media to be published through the Line Webtoon media. This is a concrete form of the comic function as a medium for various issues in which there are certain messages.

Referring to the researches described above both about digital comic content and about mapping of Indonesian comics, the novelty of this research is mapping the use of digital platforms for comics in Indonesia which will lead to the exposure of potentials arising from the presence of these technologies.

\section{PROBLEM STATEMENT}

Based on the background of the problems that have been described above, the problems in this study are generally formulated as follow: "How is the effectiveness of digital comic platform technology in Indonesia towards the existence and sustainability of the comic industry in the country?" While the problems in this study specifically can be described as follows: What is the form of the contribution of the digital comic platform in order to support the development of the creative industry in Indonesia?

\section{METHODOLOGY}

Descriptive qualitative research method was used to explain the mapping and potential of digital comic platforms that support and become part of the creative industry in the Visual Communication Design sector. This research is a phenomenology research based on the phenomenon of the use of digital comic platforms in today's society. According to Sumartono (2017: 50) phenomenological research aims to find the essence of common individual experiences or group experiences in a group of people. The subject of this research is Visual Communication Design students in Indonesia as the respondents who actively play the role as digital comic artists or passively as digital comic readers, and those who have taken courses with comic as the subject material. The object of this research is the currently available digital comic platform, one sample of comic taken purposively.

The primary data were obtained by surveying respondents from Visual Communication Design students from various universities in Indonesia based on customer experience in the use of the digital comic platform. Visual Communication Design students were chosen as respondents in this study because of several reasons including: comics are one part of their courses; visual communication design students have a habit that is close to the use of technology; and they have future opportunities to be parts of Indonesia's comic industry and creative industry. The secondary data were obtained from the national comic networking site, digital gallery networking site, and mobile applications that will be reviewed in terms of the facilities presented by the digital platform.

The analysis methods used were extrinsic and intrinsic analysis on Visual Communication Design students regarding digital platform technology. Extrinsic analysis discusses the external aspects that influence the attitudes and behavior of Visual Communication Design students, such as the environment, friends, courses and lecturers. While intrinsic analysis describes at aspects that influence the attitude of Visual Communication Design students, such as hobbies, interests, daily behavior and so on. Analysis was also carried out on statistical trends that examined the trends in digital comic platforms in Indonesia in a statistically descriptive manner with certain samples.

\section{ANALYSIS RESULTS}

In general, respondents defined the digital comic platform as a medium to read online comics, both Indonesian-made comics and translated comics, which included comic buying and selling activities, discussion forums, and works galleries. Respondents considered that the existence of the digital comic platforms was useful to get entertainment, reference for works and also medium to publish comics for free, and some others also used it to work as professional comic artists.

The digital comic platforms in this study were divided into three, namely the mobile application format, digital art gallery site format, and the comicspecific website format. Respondents in this study could choose more than one option because in reality reading comics is not a fanatic actwhere someone has no choice, so the digital platform access rating also represents the level of popularity. The highest access rating for mobile application platforms were the webtoon line $(96.39 \%)$, followed by ciayo comics $(46.3 \%)$ and webcomics $(35.2 \%)$. The highest access rates for the comic website were webtoons.com (75\%), then mangaku.web.id (39.8\%) and reoncomics.com $(30.6 \%)$. And for the highest e-gallery platform access ratings were deviantart.com $(80.6 \%)$, then kreavi.com $(44.4 \%)$ and behance.net $(34.3 \%)$. And highest genre interest were horror (43\%), followed by comedy $(40.2 \%)$ and romance (31.9). 
Most respondents accessed the digital platform using a mobile phone gadget $(98.1 \%)$. And the highest access time the platform is during spare time (88\%), the second highest was when requiring references for work $(50.9 \%)$ both professional and lecture assignments and the third highest access time was before bedtime $(22.2 \%)$

\section{DISCUSSION}

Viral trends are created by comic readers or fans that access the digital platform. The readers exchange information and also spread the information. The viral trend in addition to lifting the name of a comic also attracts its readers to read other comics on the platform, so that it can lift the popularity of its digital platform name. Technological sophistications, such as the development of gadgets and faster internet connections, are also some factors that drive the popularity of the digital comic platform.

The application platform has a higher chance of popularity compared to the other two platforms because this platform uses a gadget that has a high level of mobility and relatively smaller files. But the drawback of the mobile application platform is the amount of application software itself which if it is too much it will interfere with the work of the gadget. This platform often displays comic strip or series formats that do not take many pages. The unique thing that exists on the application platform, like LINE, is that there is a gimmick that is useful to increase the popularity of comics, for example in the form of emoticons or display themes for mobile phone and tablet gadgets.

Almost the same thing happened on websites that particularly feature comics. Website users are not too concerned about the amount of software as in a mobile application. The main obstacle of the website platform is an internet connection that is not good. In comic website platforms, comic formats similar to books are often found such as comic books, serial franchises, and serials. Not infrequently the comic websites also display a collection of scanned results from book comics or provides links to access to illegal sites, so it can be classified as copyright infringement.

The electronic gallery platform is perfect for those who often look for references either for work or personal projects. This is because the electronic gallery is not only focused on comics like on mobile applications and websites but also displays other works, such as photography, illustration, typography, and so on. Comic is only one part of this platform that is often displayed in strip format, pin up, fragments, or fanart taken and made from certain comic characters.
FanArt is the creation of fans of comics or anime as a form of their appreciation.

The trend of using the digital platform is caused by several internal and external factors. The internal factors include the desire to show their existence through comic works, the desire to achieve and get appreciation, and gain income. while the external factors include environment and technological progress.

\section{CONCLUSION}

Creative industries will always develop at any time, because creative potential and opportunities also occur at any time. In line with technological developments that always experience innovation, the potential rooted in digital platforms will also be increasingly diversed. No matter how sophisticated a gadget is, it will not be useful without capable human resources to operate it.

Comics that were originally identical with books, newspapers, or other print media using analog platforms have begun to change into digital platforms. The presence of the digital platform can also be used to detect the potential of human resources in the comic field that is increasing, both as comic artists, illustrators, script writers, and so on.

Comics are one of the fields in the visual communication design sector. In universities, especially those with art and design studies, visual communication design is one of the favorite fields. As long as there is still interest in the field of study, there is an opportunity for the availability of superior human resources in the comic field. But this does not rule out the possibility that human resources in the comic field are self-taught.

\section{REFERENCES}

1. Amanda, N., Dwi W., H., Zacky, A. (2016). Perancangan Komik Digital Menggunakan Aplikasi LINE Webtoon Tentang Pola Makan Sesuai Golongan Darah untuk Remaja. Jurnal Adiwarna, 1(8), 1-9

2. Jatnika, A.W., Hermawan, F.F. (2018). Menjadi Lelaki Sejati: Maskulinitas Dalam Komik Daring Webtoon Indonesia. Mudra Jurnal Seni Budaya, 33(1), 60-66

3. Kurnia, N. (2005). Perkembangan Teknologi Komunikasi dan Media Baru: Implikasi terhadap Teori Komunikasi. Mediator, 6(2), 291-296

4. Mataram, S. (2015). Bahasa Rupa Komik Wayang R.A. Kosasih. Jurnal Gelar, 13(1), 13-21

5. Sumartono. (2017). Metodologi Penelitian Kualitatif Seni Rupa \& Desain. Jakarta: Pusat Studi Reka Rancang Visual dan Lingkungan Universitas Trisakti

6. Tirtaatmaja, I., Nurviana, N., dan Spalanzani, A. (2012). Pemetaan Komik Indonesia Periode Tahun 1995-2008. Jurnal Wimba, 4(1), 75-91 